\title{
KARAKTERISTIK PENINGKATAN KADAR KOLESTEROL DARAH PENDERITA HIPERKOLESTEROLEMIA DI DUSUN SIDOMULYO DESA REJOAGUNG KECAMATAN PLOSO KABUPATEN JOMBANG
}

\section{Characteristics Of Increasing Blood Cholesterol Level Of Hipercolesterolemia Patients In Sidomulyo, Jombang District Rejoagung Village Ploso District Jombang}

\author{
Heni Maryati, Supriliyah Praningsih \\ Lecture of Nursing Pemkab Jombang Institute of Health Science \\ Email : nie.maryati@gmail.com, lia.praningsih@gmail.com
}

\begin{abstract}
ABSTRAK
Meningkatnya konsentrasi kolesterol dalam darah melebihi nilai normal terbukti menjadi salah satu faktor resiko penyakit jantung dan pembuluh darah penyebab kematian nomor satu di dunia. Penyebab tingginya kadar kolesterol darah diantaranya kebiasaan merokok, jenis kelamin, obesitas, aktifitas dan konsumsi serat. Penelitian ini bertujuan untuk mengidentifikasi faktor - faktor yang berhubungan dengan peningkatan kadar kolesterol darah pada penderita hiperkolesterolemia diantaranya adalah kebiasaan merokok, jenis kelamin, obesitas, aktifitas dan konsumsi serat. Tujuan lainnya ingin mengetahui variabel yang dominan mempengaruhi peningkatan kadar kolesterol darah. Desain yang digunakan adalah crossectional dimana seluruh variabel diukur dalam waktu bersamaan. Populasinya adalah seluruh penderita hiperkolesterolemia di Dusun Sidomulyo Desa Rejoagung Kecamatan Ploso Kabupaten Jombang pada Tahun 2017. Tehnik pengambilan data secara total sampling. Analisa data menggunakan uji pearson untuk melihat variabel yang signifikan terhadap peningkatan kadar kolesterol darah, sedangkan untuk mengetahui variabel dominan yang mempengaruhi peningkatan kadar kolesterol darah menggunakan uji regresi linear. Hasil analisis diperoleh variabel yang signifikan terhadap peningkatan kadar kolesterol darah adalah variabel kebiasaan merokok, obesitas, dan konsumsi serat dimana $p<0,005$. Diantara variabel di atas yang paling dominan pengaruhnya adalah konsumsi serat. Beberapa hal yang perlu direkomendasikan kepada pihak terkait untuk dapat terhindar dari terjadinya penyakit jantung akibat tingginya kadar kolesterol darah adalah berusaha keras mempromosikan lingkungan bersih asap rokok melalui mass media koran, majalah, pamphlet, liflet, atau secara langsung melalui penyuluhan dan memasyarakatkan olah raga serta gerakan konsumsi tinggi serat Mengkonsumsi makan berserat seperti buah-buahan 2 kali penyajian dalam sehari.
\end{abstract}

kata kunci : faktor-faktor, peningkatan kadar kolesterol darah

\section{ABSTRACT}

Increased concentrations of cholesterol in the blood exceeded the normal value proved to be one of the leading risk factors for heart disease and blood vessel cause of death in the world. The causes of high blood cholesterol levels include smoking habit, sex, obesity, activity and fiber consumtion. This study aims to identify factors associated with elevated blood cholesterol levels in patients with hypercholesterolaemia such as smoking habit, sex, obesity, activity and fiber consumtion. Another aim would also like to know is the dominant variable affecting the increase of blood cholesterol level. The design used is crossectional where all variables are measured at the same time. The population is all patients of hypercholesterolemia in Sidomulyo Village Rejoagung Village Ploso District Jombang Regency in the Year 2017. Techniques of data collection in total sampling. Analysis of data used Pearson test to see the significant variable to the increased of blood cholesterol level, while to know the dominant variable that influence the increased of blood cholesterol level used linear regression test. The result of the analysis showed that the significant variables on the increase of blood cholesterol were smoking habit, obesity, and fiber consumtion where $\mathrm{p}<0,005$. Among the variables at the top of the most dominant influence is consumtion of fiber. Some things that need to be recommended to related parties to avoid the occurrence of heart disease due to high blood cholesterol levels is trying hard to promote a clean environment of cigarette smoke through mass media newspapers, magazines, pamphlets, liflet, or directly through counseling and socializing sports and movement high consumtion of fiber eating fibrous foods like fruits two times a day.

keywords: factors, increased blood cholesterol level 


\section{PENDAHULUAN}

Hiperkolesterolemia

sangat

fundamental sebagai penyebab terjadinya aterosklerosis (Guyton \& Hall, 2008). Hiperkolesterolemia adalah suatu kondisi dimana meningkatnya konsentrasi kolesterol dalam darah melebihi nilai normal yang terbukti mengganggu dan mengubah struktur pembuluh darah yang mengakibatkan gangguan fungsi endotel yang menyebabkan lesi, plak, oklusi serta emboli sehingga pembuluh darah menyempit dan aliran darah tidak lancar. Inilah yang menjadi salah satu faktor resiko penyakit jantung dan pembuluh darah merupakan penyebab kematian nomor satu di dunia (Syahmani dan Sudarsih, 2010). Di Indonesia prevalensi jantung koroner berdasarkan diagnosis dokter atau gejala sebesar 1,5 persen (RISKESDAS,2013). Penyakit jantung koroner sangat erat hubungannya dengan aterosklerosis sedangkan proses aterosklerosis yang terjadi di arteri koroner adalah penyebab paling umum dari infark miokard (Libby, 2005).

Penyebab meningkatnnya kadar kolesterol paling banyak disebabkan oleh asupan makanan yang banyak mengandung lemak jenuh, pola hidup yang tidak sehat dan seimbang, gaya hidup yang salah dan kebiasaan buruk yang menjadi rutinitas sehari-hari (Anwar.dkk, 1996). Beberapa hasil telaah ilmiah mengenai penyebab tingginya kadar kolesterol darah diantaranya : 1) Kebiasaan merokok, menurut Aulia dalam Dick (2009) bahwa merokok menyebabkan gangguan metabolism lemak. Pada orang merokok ditemukan level kolesterol tinggi. Menurut Schultemaker (2002) dalam penelitiannya terhadap 492 hiperkolesterolemia diperoleh kesimpulan bahwa terdapat perbedaan yang relative nilai rata -rata total kolesterol antara perokok dan tidak perokok. Efek rokok diantaranya menyebabkan beban miokard bertambah karena rangsangan katekolamn dan menurunnya konsumsi oksigen akibat inhalasi karbondiksida yang akan menyebabkan takikardi, vasokonstriksi pembuluh darah, dan merubah 5-10 \% hemoglobin menjadi carboksi hemoglobin yang meningkatkan kolesterol tinggi sehingga diperkirakan 20\% menyebabkan stroke dan 50\% menyebabkan jantung (Morgan,2009). 2) Jenis kelamin merupakan faktor yang berhubungan dengan peningkatan kadar kolesterol, pada masa reproduksi wanita mempunyai kadar kolesterol lebih rendah sedangkan pada masa menopause akan meningkat menyamai pria. Penelitian menunjukkan prevalensi hiperkolesterolemia di Indonesia cenderung lebih banyak menyerang wanita daripada laki -laki pada usia 55 tahun ke atas (Brata,2009). 3) Obesitas, menurut Wodd, dkk dalam penelitian Manurung (2003) pada penderita obesitas terjadi dyslipidemia ditandai hipertrigliserida dan penurunan HDL yang disebabkan oleh penurunan insulin yang meningkatkan aliran lemak bebas sehingga meningkatkan kolesterol. 4) Aktivitas merupakan salah satu factor terkait kolesterol. Penelitian Raul (2009) menunjukkan tingkat aktivitas memiliki hubungan terhadap penurunan kadar kolesterol total. Sedangkan menurut Kraus dalam Manurung (2003) bahwa olah raga secara teratur memberikan efek peningkatan sensitivitas metabolism lipid. 5) Konsumsi serat, menurut penelitian Tjoktroparwiro (2006) dengan konsumsi serat dari sayuran golongan A dab golongan B memperbaiki glucose uptake dari jaringan perifer, memperbaiki kepekaan sel beta pancreas dan meningkatkan kadar kolesterol HDL kolesterol darah Upaya untuk mengetahui seberapa besar pengaruh kebiasaan merokok, jenis kelamin, obesitas, aktivitas, diet rendah lemak terhadap peningkatan kadar kolesterol sangatlah penting karena peningkatan kolesterol memiliki dampak terhadap system pembuluh darah yang berfungsi memberi kehidupan organ -organ vital seperti jantung, otak, ginjal, paru - paru dan lainnya. Selain itu penelitian juga sebagai preventif terhadap kemungkinan banyaknya kasus gangguan system tubuh tertentu seperti penyakit jantung koroner, stroke dan penyakit gangguan pembuluh darah lainnya yang disebabkan peningkatan kolesterol darah mengingat $80 \%$ peningkatan kadar kolesterol karena gaya hidup dan sisanya karena faktor yang tidak dapat dikendalikan. Berdasarkan permasalahan di atas peneliti tertarik untuk melakukan penelitian tentang Karakteristik Peningkatan Kadar Kolesterol Darah Penderita Hiperkolesterolemia di Dusun Sidomulyo Desa Rejoagung Kecamatan Ploso Kabupaten Jombang, mengingat Penyakit pembuluh darah merupakan 10 besar penyakit di Wilayah Kerja Puskesmas 
Bawangan termasuk di Dusun Sidomulyo dimana hasil studi pendahuluan dengan pemeriksaan kadar kolesterol darah mayoritas kadar kolesterol darah > 200 $\mathrm{mg} / \mathrm{dl}$.

\section{METODE PENELITIAN}

Jenis penelitian yang digunakan adalah penelitian analitik korelasional dengan pendekatan cross sectional. Popolasi adalah penderita hiperkolesterolemia di Dusun Sidomulyo Desa Rejoagung Kecamatan Ploso Kabupaten Jombang sejumlah 34 orang, dengan menggunakan total sampling, Penelitian dilakukan di Dusun Sidomulyo Desa Rejoagung Kecamatan Ploso Kabupeten Jombang pada Bulan September 2017. Alat pengumpulan data penelitian ini berupa kuesioner, meteran, Timbangan, alat tes kolesterol digital. Analisis yang digunakan adalah analisa univariat untuk melihat distribusi frekuensi data dan atau proporsinya, analisa bivariat analisis hubungan antara variable kovarian dengan variable dependennya guna mengetahui kekuatan hubungannya satu persatu. Uji statistic yang digunakan adalah pearson dengan tingkat kemaknaan 0,5 pada CI 95\% serta analisa multi variate menggunakan regresi linear untuk mengetahui hubungan beberapa variabale determinan (independen) seperti kebiasaan merok, jenis kelamin, obesitas, aktivitas dan diet serat dihubungkan terhadap variable dependen (kadar kolesterol darah)

\section{HASIL PENELITIAN}

Tabel 1. Karakteristik responden yang mengalami peningkatan kadar kolesterol darah di Dusun Sidomulyo Desa Rejoagung.

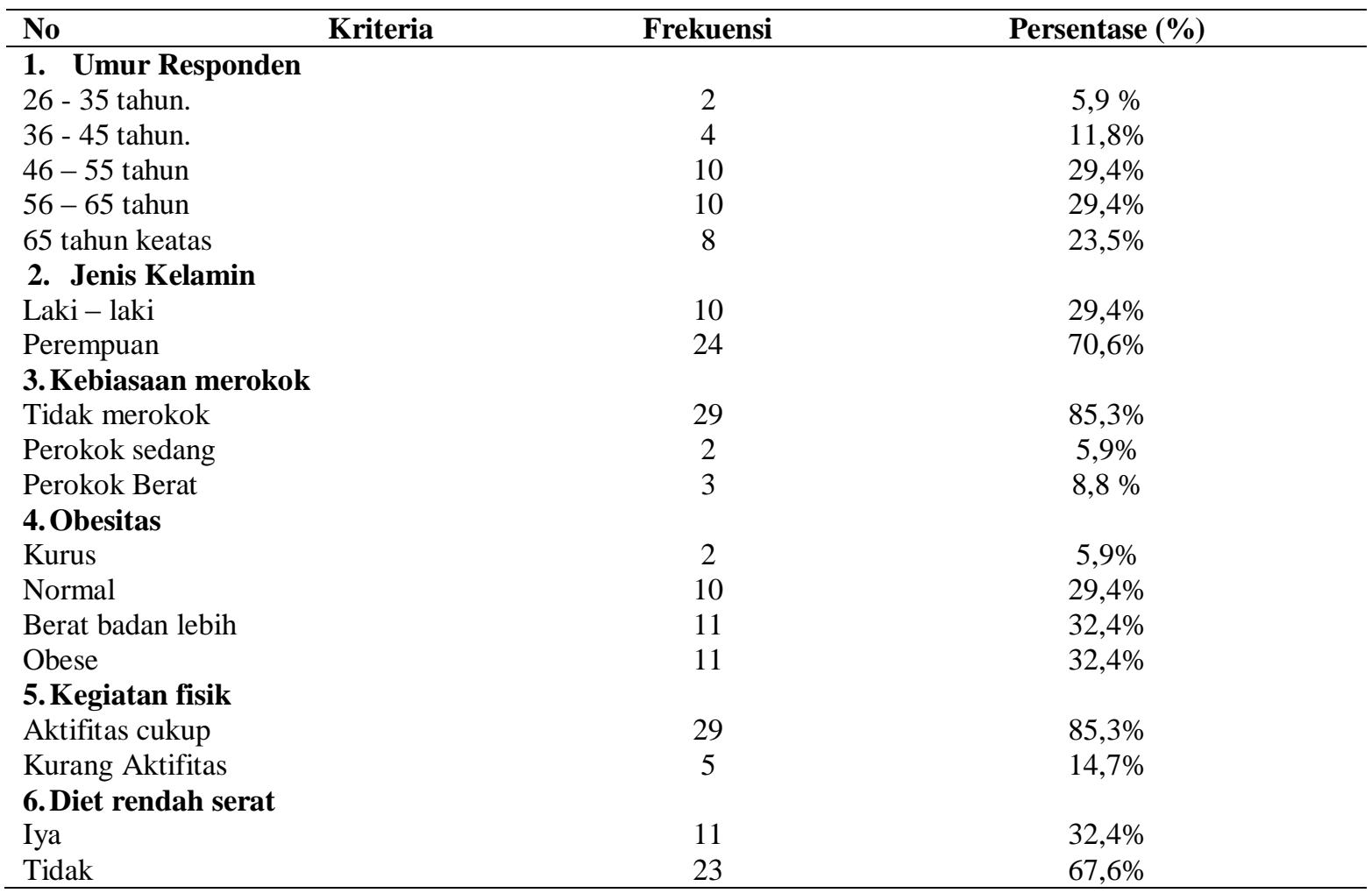

Sumber : Data primer 2017

Tabel 2.Distribusi Frekuensi Responden berdasarkan kadar kolesterol darah di Dusun Sidomulyo Desa Rejoagung. 


\begin{tabular}{lllcc}
\hline No & & Kriteria & Frekuensi & Persentase (\%) \\
\hline 1. & Sedang $(200-239 \mathrm{mg} / \mathrm{dl})$ & & 11 & $32,4 \%$ \\
2. & Tinggi $(>240 \mathrm{mg} / \mathrm{dl})$ & & 23 & $67,6 \%$ \\
& & Total & 34 & $100 \%$ \\
\hline
\end{tabular}

Sumber : Data Primer, 2017

Dari tabel di atas menunjukkan sebagian besar $(67,6 \%)$ responden yang mengalami peningkatan kadar kolesterol darah dalam kategori tinggi > $240 \mathrm{mg} / \mathrm{dl}$. Dari Output Korelasi Pearson diatas dapat diketahui bahwa Nilai Signifikansi masing-masing variabel adalah $<0,05$, yang berarti terdapat korelasi yang signifikan, kecuali variabel Kegiatan Fisik nilai signifikansi. nilai signifikansi 0,154 >0,05 dan variabel Jenis

\section{PEMBAHASAN}

Faktor - faktor yang berhubungan dengan peningkatan kadar kolesterol darah

Berdasarkan data pada tabel menunjukkan bahwa hasil analisa data diperoleh nilai p-value 0,088 atau dengan kata lain p-value > $\alpha$, maka dapat disimpulkan bahwa jenis kelamin tidak signifikan dalam peningkatan kadar kolesterol darah penderita hiperkolesterolemia di Dusun Sidomulyo Desa Rejoagung Kecamatan Ploso Kabupaten Jombang. Berdasarkan data yang didapatkan dari hasil penelitian diketahui bahwa sebagian besar $(70,6 \%)$ responden yang mengalami peningkatan kadar kolesterol darah berjenis kelamin laki -laki. Jenis kelamin mempengaruhi tingginya kadar kolesterol seseorang. Pada umumnya pria yang memasuki usia 40 tahun ke atas dan wanita umumnya ketika memasuki masa menopause (Syahmani dan Sudarsih,2010). Jadi berdasarkan hasil penelitian tidak hanya responden berjenis kelamin laki - laki yang mengalami peningkatan kadar kolesterol tetapi pada responden wanita juga yang mana hampir setengahnya $(29,4 \%)$ responden yang mengalami peningkatan kadar kolesterol darah berusia 46 - 55 tahun dan 56 -65 tahun dimana usia tersebut sudah memasuki menopause yang berisiko terjadi peningkatan kadar kolesterol

Hubungan kebiasaan merokok dengan
peningkatan kadar kolesterol darah
penderita hiperkolesterolemia

Kelamin nilai signifikansi 0,623 > 0,05 yang berarti tidak terdapat korelasi yang signifikan. Sedangkan berdasarkan uji regresi didapatkan hasil Nilai Beta $\beta$ (Coefficients) yang paling menjauhi Nol (0) adalah variabel Diet Serat, dengan demikian variabel yang paling dominan adalah variabel Diet Serat

Berdasarkan data pada tabel menunjukkan bahwa hasil analisa data diperoleh nilai $\mathrm{p}$-value 0,005 atau dengan kata lain $p$-value $<\alpha$, maka dapat disimpulkan bahwa kebiasaan merokok signifikan dalam peningkatan kadar kolesterol darah penderita hiperkolesterolemia di Dusun Sidomulyo Desa Rejoagung Kecamatan Ploso Kabupaten Jombang. Berdasarkan data yang didapatkan dari hasil penelitian diketahui bahwa hampir seluruhnya $(85,3 \%)$ responden yang mengalami peningkatan kadar kolesterol darah tidak merokok. Dalam sebuah penelitian yang dilakukan oleh Dr. Adam Gepner dari sebuah University of Wisconsin School of Medicine and Publich Health di Madison, Amerika Serikat menyatakan bahwa rokok meningkatkan kolesterol jahat dalam darah dan membunuh kolesterol baik. Dari hasil penelitian bahwa responden yang mengalami peningakatan kadar kolesterol hampir seluruhnya tidak merokok hal di ini dikarenakan sebagian besar $(70,6 \%)$ responden berjenis kelamin perempuan dan tidak merokok sehingga peningkatan kadar kolesterol di mungkinkan karena faktor lainnya.

\section{Hubungan obesitas dengan peningkatan kadar kolesterol darah penderita hiperkolesterolemia \\ Berdasarkan data pada tabel menunjukkan bahwa hasil analisa data diperoleh nilai $\mathrm{p}$-value 0,003 atau dengan kata lain $p$-value $<\alpha$, maka dapat}


disimpulkan bahwa obesitas signifikan dalam peningkatan kadar kolesterol darah penderita hiperkolesterolemia di Dusun Sidomulyo Desa Rejoagung Kecamatan Ploso Kabupaten Jombang. Berdasarkan data yang didapatkan dari hasil penelitian diketahui bahwa hampir setengahnya $(32,4 \%)$ responden yang mengalami peningkatan kadar kolesterol darah mempunyai berat badan lebih dan obese. Seseorang yang kelebihan berat badan identik dengan tubuh yang menyimpan banyak lemak dan kalori. Seseorang yang kelebihan berat badan rentan terhadap suatu penyakit termasuk kolesterol. Orang obese kadar adenopektin menurun kadarnya yang memicu terjadinya diabetes mellitus dan penyakit jantung coroner serta stroke karena adenopektin sebagai antiaterogenik yang dapat menghambat pembentukan aterosklerosis (Syahmani dan Sudarsih,2010).

\section{Hubungan aktivitas dengan peningkatan kadar kolesterol darah penderita hiperkolesterolemia}

Berdasarkan data pada tabel menunjukkan bahwa hasil analisa data diperoleh nilai p-value 0,107 atau dengan kata lain $\mathrm{p}$-value $>\alpha$, maka dapat disimpulkan bahwa kegiatan fisik tidak signifikan dalam peningkatan kadar kolesterol darah penderita hiperkolesterolemia di Dusun Sidomulyo Desa Rejoagung Kecamatan Ploso Kabupaten Jombang. Berdasarkan data yang didapatkan dari hasil penelitian diketahui bahwa hampir seluruhnya $(85,3 \%)$ responden yang mengalami peningkatan kadar kolesterol darah mempunyai aktifitas cukup. menurut penelitian Raul (2009) bahwa tingkat aktivitas memiliki hubungan bermakna terhadap penurunan kadar kolesterol total. Seseorang yang melakukan olah raga secara teratur akan meningkatkan kadar HDL, penurunan LDL dan trigliserida. Pada wanita tidak memberikan respon secepat pria (Natural,2005). Berdasarkan hasil penelitian kegiatan fisik tidak signifikan dalam peningkatan kadar kolesterol darah dimungkinkan karena sebagian besar $(70,6 \%)$ responden yang mengalami peningkatan kadar kolesterol darah berjenis kelamin perempuan dimana aktivitas wanita tidak memberikan respon secepat pria dalam meningkatkan kadar HDL serta menurunkan kadar LDL dan trigliserida. Selain itu menurut WHO (2004) aktivitas fisik yang dimakksud adalah kegiatan paling sedikit sepuluh menit tanpa berhenti melakukan aktifitas fisik ringan, sedang dan berat, dimana hasil penelitian aktivitas yang dilakukan responden adalah bekerja di sawah yang mana kadang tidak setiap hari dan tidak teratur.

\section{Hubungan diet serat dengan peningkatan kadar kolesterol darah penderita hiperkolesterolemia}

Berdasarkan data pada tabel menunjukkan bahwa hasil analisa data diperoleh nilai p-value 0,002 atau dengan kata lain $p$-value $<\alpha$, maka dapat disimpulkan bahwa diet serat signifikan dalam peningkatan kadar kolesterol darah penderita hiperkolesterolemia di Dusun Sidomulyo Desa Rejoagung Kecamatan Ploso Kabupaten Jombang. Berdasarkan data yang didapatkan dari hasil penelitian diketahui bahwa menunjukkan sebagian besar $(67,6 \%)$ responden yang mengalami peningkatan kadar kolesterol darah tidak melakukan diet serat. Penyebab meningkatnya kadar kolesterol paling banyak disebabkan oleh asupan makanan yang banyak mengandung lemak jenuh, selain itu juga rendahnya diet serat dimana konsumsi makanan miskin serat khususnya serat larut dihubungkan dengan rendahnya kadar serum HDL kolesterol yang diperlukan untuk mencegah aterosklerosis. Kebutuhan serat makanan 25 - 35 gram per hari. Konsumsi serat makanan yang cukup dapat menurunkan kolesterol darah 10 -15 persen . Menurut penelitian prospektif oleh Tjoktroparwito (2006) membuktikan bahwa konsumsi diet B (68\% kalori karbohidrat, 20\% kalori lemak dan $12 \%$ kalori protein yang banyak mengandung serat sayuran golongan $\mathrm{A}$ dan sayuran golongan B dapat memperbaiki pembakarn glukosa dari jaringan perifer dan meningkatkan kadar HDL).

Faktor yang paling dominan pengaruhnya terhadap peningkatan kadar kolesterol darah penderita hiperkolesterolemia

Berdasarkan hasil penelitian faktor faktor yang berhubungan dengan peningkatan kadar kolesterol darah penderita hiperkolesterolemia di Dusun Sidomulyo Desa Rejoagung Kecamatan Ploso Kabupaten Jombang faktor yang signifikat 
terhadap peningkatan kolesterol darah adalah faktor kebiasaan merokok, obesitas, dan diet serat dan berdasarkan uji regresi didapatkan hasil nilai Beta $\beta$ (Coefficients) yang paling menjauhi nol (0) adalah variabel diet serat, dengan demikian variabel yang paling dominan dalam peningkatan kadar kolesterol darah pada penderita hiperkolesterolemia di Dusun Sidomulyo Desa Rejoagung Kecamatan Ploso Kabupaten Jombang adalah variabel Diet Serat. Berdasarkan data yang didapatkan dari hasil penelitian diketahui bahwa menunjukkan sebagian besar $(67,6 \%)$ responden yang mengalami peningkatan kadar kolesterol darah tidak melakukan diet serat dimana sebagian besar $(67,6 \%)$ responden yang mengalami peningkatan kadar kolesterol darah dalam kategori tinggi $>240 \mathrm{mg} / \mathrm{dl}$. Banyak hal yang menjadi pemicu tingginya kolesterol dalam darah. Penyebab meningkatnya kadar kolesterol paling banyak disebabkan oleh asupan makanan yang banyak mengandung lemak jenuh, pola hidup yang tidak sehat dan seimbang, gaya hidup yang salah dan kebiasaan buruk yang menjadi rutinitas sehari -hari (Anwar,dkk,1996). Diet serat merupakan faktor dominan yang signifikat terhadap peningkatan kadar kolesterol darah , dimana fungsi makanan berserat adalah menurunkan kolesterol dalam darah. Rendahnya konsumsi serat terutama serat larut berhubungan dengan rendahnya kadar serum HDL kolesterol yang diperlukan untuk mencegah aterosklerosis. Kebutuhan serat makan adalah 25 -35 gram perhari. Konsumsi serat makanan dalam jumlah yang cukup akan menurunkan kolesterol darah $10-15 \%$

\section{KESIMPULAN DAN SARAN Kesimpulan}

Berdasarkan hasil penelitian sebagian besar (67,6\%) responden di Dusun Sidomulyo Desa Rejoagung Kecamatan Ploso Kabupaten Jombang mengalami peningkatan kadar kolesterol darah dalam kategori tinggi $>240 \mathrm{mg} / \mathrm{dl}$. Dari analisis statistik yang telah dilakukan dan pembahasan yang telah dikemukakan, dapat disimpulkan bahwa faktor yang signifikan terhadap peningkatan kolesterol darah penderita hiperkolesterolemia adalah faktor kebiasaan merokok, obesitas, serta diet serat. Dari faktor tersebut faktor yang paling dominan dalam peningkatan kadar kolesterol darah adalah diet serat. Berdasarkan hasil penelitian sebagian besar $(67,6 \%)$ responden di Dusun Sidomulyo Desa Rejoagung Kecamatan Ploso Kabupaten Jombang mengalami peningkatan kadar kolesterol darah dalam kategori tinggi > $240 \mathrm{mg} / \mathrm{dl}$. Dari analisis statistik yang telah dilakukan dan pembahasan yang telah dikemukakan, dapat disimpulkan bahwa faktor yang signifikan terhadap peningkatan kolesterol darah penderita hiperkolesterolemia adalah faktor kebiasaan merokok, obesitas, serta diet serat. Dari faktor tersebut faktor yang paling dominan dalam peningkatan kadar kolesterol darah adalah diet serat

Saran

Bagi Penderita Hiperkolesteromia

Mengurangi asupan makanan yang banyak mengandung lemak jenuh, melakukan pola hidup sehat dan seimbang, merubah gaya hidup yang salah dan kebiasaan buruk yang menjadi rutinitas sehari -hari dan melakukan pemeriksaan kolesterol dan tekanan darah secara teratur dalam upaya pencegahan penyakit, khususnya penyakit akibat kolesterol yaitu Stroke, hypertensi dan Penyakit Jantung Koroner (PJK)

\section{Bagi Perawat}

Berusaha keras mempromosikan lingkungan bersih asap rokok melalui mass media koran, majalah, pamphlet, liflet, dan memasyarakatkan olah raga serta gerakan konsumsi tinggi serat Mengkonsumsi makan berserat seperti buah-buahan 2 kali penyajian dalam sehari dengan sasaran kelompok kelompok dan tempat tempat yang strategis. juga dapat secara langsung melalui penyuluhan-penyuluhan. Peneliti Selanjutnya Dibutuhkan penelitian dengan telaah ilmiah lebih jauh dengan variabel analisis yang lebih kompleks dan terkait dengan kadar kolesterol, menggunakan analisa dan uji statistic serta desain penelitian yang lebih mendalam

\section{DAFTAR PUSTAKA}

Anwar,dkk.1996. Pengantar Praktikum Kimia Organik. Depdikbud. Jakarta

Libby.P.The pathogenesis, prevention, and treatment of atherosclerosis. In: Fauci AS, Braunwald E, Kasper DL, Hausen SL, Longo DL, Jameson $\mathrm{JL}$,et al, editors, Harrison's principles 
of internal medicine. $17^{\text {th }}$ ed. New

York "Mc Graw Hill008,p.1501-3

Manurung, Elvi.2003. Hubungan antara Asupan lemak tak jenuh tunggal dengan kadar kolesterol igh Density Lipoprotein plasma penderita penyakit jantung koroner. Tesis.Program Pendidikan Pasca Sarjana. UI. Jakarta

Raul.2009. Low and Hight Density Lipoprotein Cholesterol Goald Attainment in Dyslipidemic women : The Lipid Treatment Assesment Project (LTAP) 2. American Journal.12/01/2009.American Heart Journal.2009.158 (5)86 -866@ 2009 Mosby inc

Schultemaker.2002, July. Relationship between smoking habits and low density lipoprotein.cholesterol,high density lipoprotein.cholesterol and triglycerides in a percholesterolemic adult cohort, in relation to gender and age, clinical and experimental Medicine.83

$-88$. Monday,July.01.2002.http://www.pr oquest.com/dq web

Syahmani dan Sudarsih.2010. Penuntun Praktikum Biokimia. FKIP.Unlam.Banjarmasin

Tjoktroparwiro.2006. Hidup sehat dan bahagia bersama Diabetes Mellitus. Jakarta : PT Gramedia Pustaka Utama 